\title{
PSYCHOLOGICAL DETERMINANTS OF LIFE BALANCE
}

\section{PSYCHOLOGICZNE DETERMINANTY BILANSU ŻYCIOWEGO}

\author{
${ }^{1}$ Department and Clinic of Geriatrics of the Nicolaus Copernicus University in Torun \\ Collegium Medicum in Bydgoszcz \\ ${ }^{2}$ student Collegium Medicum in Bydgoszcz
}

\begin{abstract}
S u m mary
The problem of life balance in the elderly has been of interest of many scientists who have undertaken research in different environments and among large populations. As a

result of these studies, key determinants of life balance, which mainly affect the positive or negative balance of life in the elderly, have been developed.
\end{abstract}

\section{Streszczenie}

Problem bilansu życiowego ludzi w podeszłym wieku interesował wielu naukowców, którzy podejmowali badania w różnych środowiskach i na dużych liczebnie populacjach. W wyniku tych badań opracowane zostały najważniejsze

Key words: determinants, life balance, older age

Stowa kluczowe: determinanty, bilans życiowy, wiek podeszły

Determinants are the factors a function of which is to set (determine) something; in the context of the manuscript - a reason conditioning phenomena and relations between them $[1,2]$.

Balance in life studies described by M. Susułowską (1989) covered a population of more than 300 people aged from 60 to 87 years. The average age of men was 71.2 and women - 73.4. The studied group was diverse in terms of social origin, education and living conditions. It consisted of people living together with a spouse or children, alone and in a retirement home. The study used the following methods: conversation, standardized interview with questions on the assessment of individual life periods and, created for the purposes of the research, test of unfinished sentences. determinanty bilansu życiowego, które w głównej mierze wpływają na dodatni bądź ujemny bilans życiowy osób w starszym wieku.

Respondents were divided into three groups based on their life evaluation, i.e. people with a positive, negative and ambiguous balance of life. Among people with a positive balance of life were those who were pleased with their life and would not change anything. The second group (negative balance of life) included those who evaluated their life as lost and who would like to live it once again to change it. The last group (ambiguous balance of life) was represented by people who were not sure about evaluation as they were satisfied with some events in their life while they would change the others.

The main objective of this study was to determine the most important factors that affect the positive or negative balance of life in the elderly. The study found no significant relationship between age and kind of 
balance. There was also no significant correlation between the balance of life and education. In addition, there is no significant relationship between financial situation and the balance. The positive balance is more common in men than in women, although this difference is not statistically significant. Women are more likely than men to describe their health as bad or average; however, the studies found no significant correlation between the kind of balance and subjective assessment of their health. A factor that is associated with a positive balance in older men and women is a successful family life.

The overall assessment of life was largely influenced by the current situation in life. The best life situation was found in those persons whose spouse was alive, and with whom they lived, having at the same time rewarding relationship with your children. In the process of assessing the current situation in life requirements could be seen as less demanding. If the older man had someone who would take care of him in case of illness and felt safe because of this, he would be satisfied with his current situation. The study can be concluded that the current situation in life and is currently considered hierarchy of values have a greater impact on the overall summary of life than objective successes and failures. The man who enjoys relatively good health in an old age, is provided with at least modest living conditions, and can count on the family, which make him feel loved, needed and respected, is inclined to define his life as successful. In contrast, a negative evaluation of life is presented by the elderly who, for various reasons, had been abandoned or left lonely in the old age.

The surveyed could be divided into two groups. The first one included those who did not justify their conduct attributing the misfortunes to themselves. The other group was created by people who have seen the reasons for their failures in fate.

Many respondents revealed that childhood - when compared with subsequent years of age - was a happy stage of their lives, although many people admitted that it was often a difficult period. The remaining stages of life were summarized in different ways. The fact that the subjects belonged to the generation that entered adulthood during the Second World War. This stage of life was evaluated as significant for their further fate in a negative way since they lost their loved ones, were held in concentration camps and prisons, often losing their entire estate.
Each phase of life were assessed differently depending on gender. In the summary of their own life a major role in women played such emotional factors as disappointment about love and marriage. On the other hand, a greater role men's assessment of life was played by achievements and failures at the professional level.

Other studies on the balance of life of older people presented by Susułowską (1989) were carried out by H. Sawicka. She studied 40 men and 40 women, who were over 60 years old. The mean age was 71.6 years for men, 74.5 for women. Respondents lived in a state pensioner's home, with a family or in their own homes. The main research method was the clinical history, complemented by the assessment of the stages of life. Sawicka divided the subjects into: people who evaluated their life as successful; those that were not able to clearly assess their life and those dissatisfied who had a feeling of wasted life.

The author of this research aimed to find out what significantly influences the attitude of the elderly towards their past. Statistical analysis indicated a lack of relationship between the kind of balance and age and gender. In women, level of education slightly correlated with a more positive evaluation of life. In both men and women good relationships with their spouse influenced the favorable evaluation of life, while death of a spouse underestimated this evaluation. In women, this dependence was much stronger than in men.

The results of the importance of work turned out interestingly indicating that physical work performed since early childhood, especially in difficult conditions, was a source of pride for men and influenced their life balance positively. In women, in contract, it was a source of bitterness and negative assessment of past years. For both sexes, the factor highly correlating with a positive evaluation of life, was their satisfaction with their job situation, which was an indicator of the degree of sense of freedom to choose the time and type of work.

Sawicka came to the conclusion that the key determinant of the balance in life for both sexes is the possibility of self-realization, which gets more perfect with freedom of choice of activity that our life will be devoted to. Self-realization can be achieved in both professional as well as in family life. In addition, similarly to Susułowska's conclusions, she has proved that current life situation has an enormous influence on life evaluation. In women and men high correlation 
between positive balance of life, and the following factors was noted: maintaining social contacts, having personal interests or passions in life, maintaining good relationships with children. An important role was played also by good health and active lifestyle; however, their importance was greater in men.

Regardless of the gender of the study participants, loneliness had a negative influence on their life balance evaluation. It was expressed by lack of contact with the close ones and a sense that the current living conditions (mainly staying in a state institution) are a necessity, not a result of their own choice. Men were more likely to evaluate the past years taking into account their present situation i.e. they emphasized those situations that influenced their present living conditions. In contrast, women expressed greater independence when talking about their current situation. They emphasized their past achievements even if they did not allow them to avoid their current living conditions. from the current situation, in which they happen to live in old age, paying attention to past achievements, even if they did not save them from finding themselves in the present conditions of life.

In the summary of her research Sawicka states that men when evaluating their life balance pay attention primarily to the events that help in self-realization aimed at better economic situation or events that can protect them against helplessness and ineptitude. However, women pay attention to elements of emotional nature i.e. happy marriage, good upbringing of children, possibility of choice between family and professional role. The factors influencing both sexes' more favorable balance of life are having hobbies and keeping in touch with social environment, even in old age, that support their activity.

H. Susułowska states that studies about the balance of life of older people indicate a rare occurrence of explicit - positive or negative - evaluation of their life. People very often accept their life as it has been lived, while, at the same, minority of people declares that, if given a chance, they would live their life over again the same way.

As essential to balance of life of older people should be considered such determinants as: the current situation in life, certain personality traits, emotional and social maturity and the ability to achieve goals recognized by this person as valuable [3].

In the research work in the field of psychology, it is emphasizes that subjects who are married, with children, or people with stable family life, usually more optimistically evaluated their past than people living alone. Also, people satisfied with their work and successful in the professional field were more positive about the past. The scientists investigating the field of the elderly, see a clear link between a positive balance of life and well-being. On the other hand, negative life balance influences evaluation of health [4].

Also Z. Świderska in his study tried to answer the question - what affects the outcome of the balance of life? Her survey included people aged 60 to 94 years. The author came to the conclusion that the greater impact on the evaluation of life balance comes from current life situation than childhood. assessment of the current situation of man than the time of childhood. The only factor of youth, which is associated with positive assessment of life, is the presence of significant people. Among people dissatisfied with their life, $88 \%$ did not have someone like that aside. The type of balance is also affected by a sense of control over their own lives. The surveyed who evaluated their past in a positive way, felt they had been the authors of their own biography, while in turn, people who were dissatisfied with the past were of an opinion that their past choices were a result of various factors from the outside. Self-image is of great significance as well. People with a negative balance often pay attention to changes in your own body happening under because of the aging process. Interestingly, people with a negative balance see the world in dark colors, filled with crimes and wars, while positively assessing people see the welfare and progress of present times. Life satisfaction is also affected by the ability to see the beauty of nature. The joy of life, especially among farmers, was to work in harmony with nature. The author of these studies emphasizes that satisfaction with the past in the old age is rewarding as it is easier to tolerate various health problems, people have less fears and more plans for future and they cooperate with doctors more willingly [5].

A. Tokaj describes her research conducted among 510 people aged from 60 to 70 years - residents of a district of Poznan. The study concerned the nature of the life of older people, their balance of life and types of old age. 364 women and 146 men were investigated. Out of this group, satisfaction with the past was revealed by 284 people (55.29\% of all respondents). The factors that influenced these patients' positive balance of life were consistent married life and family relations, job satisfaction, satisfactory economic 
situation, lack of serious health problems, satisfaction with the achievements and the ability to selfdevelopment, life in accordance with recognized ethical code [6].

In the opinion of respondents a change in positive attitude towards the past can fostered by such circumstances as: serious health problems of the person or their close ones, deterioration of economic situation, death of a close person, loneliness, lack of goodwill of the environment.

For 58 respondents (11.37\% of total) life was average. The following factors contributed to the intermediate life balance: the average family relationships, difficulties in reconciling work and family chores, no clear successes in life, lack of opportunities for self-realization, inability to solve problems independently.

Negative evaluation of past life in 52 people (10.2\% of all respondents) resulted mainly from: the negative experiences of the Second World War, instability of political and social transformations in Poland, pathology in family life, hard, dissatisfactory professional work, inability to self-improvement, inability to reconcile personal life with work responsibilities, lack of purpose in life and inability to control it.

For the above-mentioned study it can be concluded that the determinants (factors affecting the evaluation of past life in the elderly) are very diverse. These factors are of biological (e.g. health), psychological (e.g. emotional contact with your loved ones) and social nature (e.g. economic situation). They may affect the balance of life with distant time perspective (from the past) or from the perspective of the current situation (of the present) [7,8].

\section{REFERENCES}

1. Kopaliński W.: Słownik wyrazów obcych i zwrotów obcojęzycznych. Wiedza Powszechna, Warszawa 1971.

2. Tokarski J. (red.): Słownik wyrazów obcych. PWN, Warszawa 1980.

3. Susułowska M.: Psychologia starzenia się i starości. Warszawa: PWN, Warszawa 1989.

4. Frąckiewicz L., Żakowska-Wachelko B.: 300 wiadomości o starości. Katowice: Śląski Instytut Naukowy, Katowice 1987.

5. Świderska Z. H.: Bilans życia. Charaktery, 1999, 48.

6. Tokaj A.: U progu starości. Wydawnictwo Eruditus, Poznań 2000.

7. Izdebski P., Polak A.: Bilans życia i poczucie koherencji osób starszych w zależności od ich aktualnej sytuacji życiowej. Gerontologia Polska 2005: 13(3) s. 188-194.

8. Zielińska-Więczkowska H., Kędziora-Kornatowska K.: Determinanty satysfakcji życiowej w późnej dorosłości w świetle rodzimych doniesień badawczych. Psychogeriatria Polska, 2010; 7(1):11-16.

Address for correspondence:

Anna Polak-Szabela

Department and Clinic of Geriatrics

of the Nicolaus Copernicus University in Torun

Collegium Medicum in Bydgoszcz

85-094 Bydgoszcz

M. Curie-Skłodowskiej 9 Street

tel. (52) 585-49-00

fax (52) 585-49-21

e-mail: annapolak1979@wp.pl

Katarzyna Porzych (e-mail: kikgeriat@cm.umk.pl)

Martyna Porzych (e-mail: martyna_porzych@wp.pl)

Kornelia Kędziora-Kornatowska

(e-mail: kikgeriat@cm.umk.pl)

Received: 17.03.2015

Accepted for publication: 8.06.2015 